\title{
Entre Prisões da I magem, I magens da Prisão: um dispositivo tecno-poético para uma clínica do trabalho
}

Fernanda Spanier Amador

Orientadora: Tania Mara Galli Fonseca

Co-orientadora: Maria Cristina Vilanva Biazus

Data da defesa: 08 de maio de 2009

Esta tese aborda dois temas centrais imagem e subjetivação, os quais desdobram-se em três outros temas transversos: trabalho, que ganha a cena nesta tese enquanto atividade, clínica, a qual pensamos por entre as formulações da Clínica da Atividade e procedimentos de Crítica e Clínica e tecnologias digitais de imagem, em seus potenciais de estetização de si e do trabalho. Situada em uma Casa Albergue Feminino, destinada a mulheres que cumprem pena em regime semi-aberto, a pesquisa teve como objetivo geral a criação de um campo de experimentação da atividade prisional pelo emprego de recursos tecnológicos de videografia digital junto a trabalhadoras agentes do sistema penitenciário. Assim, o eixo da tese consiste no dispositivo que propusemos para disparar uma análise das situações de trabalho na prisão, o qual intitulamos Tenco-Poético de Análise da Atividade, para fins de confrontação com situações do trabalho na prisão por meio do uso de câmera de vídeo e de computadores para edição de imagens. Exploramos, então, as peculiaridades da atividade de produção de imagens sobre o trabalho prisional ressaltando as imbricações entre ver, pensar e falar visando suas potencialidades para deflagrar um processo de pensamento por imagens acerca da atividade de trabalho, o que caracteriza uma vertente metodológica no percurso desta tese. Dedicamo-nos ainda, uma vertente teórica, pela qual operamos um tensionamento conceitual visando abrir veredas no que se refere à construção de possibilidades para uma Clínica do Trabalho valendo-se das ferramentas analíticas da Filosofia da Diferença, da Ergologia e da Clínica da Atividade, que enfatize a afirmação do que está em vias de diferir no plano do pensamento no curso das atividades de trabalho, enlaçando os planos dos fazeres profissionais, das tramas institucionais e da subjetivação. Buscando uma espécie de expansão do poder de ver que, as cenas produzidas pelas agentes com o uso da câmera e do software de edição, dão o testemunho de um processo pelo qual o pensamento sobre a atividade prisional foi acionado pelo próprio dispositivo imagético.

Palavras-chave: Imagem. Subjetivação. Atividade. Clínica. Tecnologias digitais.

Referência: AMADOR, Fernanda Spanier. Entre Prisões da Imagem, Imagens da Prisão: um dispositivo tecno-poético para uma clínica do trabalho. Orientadora: Tania Mara Galli Fonseca. Coorientadora: Maria Cristina Vilanva Biazus. 2009. Tese (doutorado) - Programa de Pós-Graduação em Informática na Educação, Centro de Estudos Interdisciplinares em Novas Tecnologias da Educação, Universidade Federal do Rio Grande do Sul, 2009, Porto Alegre. 